\title{
High seropositivity of IgG and IgM antibodies against cytomegalovirus (CMV) among HIV-1 seropositive patients in Ilorin, Nigeria
}

\author{
Adeola Fowotade ${ }^{1}$, Iheanyi Omezuruike Okonko², Olajide Olubunmi Agbede ${ }^{3}$, S T Suleiman ${ }^{3}$
}

1. Department of Medical Microbiology \& Parasitology, University College Hospital, Ibadan, Nigeria

2. Medical Microbiology Unit, Department of Microbiology, University of Port Harcourt, P.M.B. 5323, Choba, East-West Road, Port Harcourt, Nigeria 500102

3. Department of Medical Microbiology \& Parasitology, University of Ilorin Teaching Hospital, Ilorin, Nigeria

\begin{abstract}
Background: Human immunodeficiency virus/acquired immunodeficiency syndrome (HIV/AIDS) is a major public health problem in sub-saharan Africa. Cytomegalovirus (CMV) has been reported to enhance HIV replication and accelerate the progression of HIV infection to AIDS.

Objective: This study reports on the high seropositivity of immunoglobulin (Ig) G and M antibodies against CMV and the risk factors for CMV infection among HIV/AIDS patients in Ilorin, Nigeria.

Method: A total of 180 consented HIV-1 seropositive patients (age-range 16-56 years; 108 females and 72 males) were consecutively recruited. Socio-demographic/behavioral data and $5 \mathrm{ml}$ blood samples were collected from each patient. Plasma of each sample was assayed for anti-CMV IgG/IgM using a CMV IgG and IgM Enzyme Linked ImmunoSorbent Assay (ELISA) kit.

Results: Twenty (11.1\%) of the 180 HIV-1 seropositive subjects were positive for anti-CMV IgM antibody while 169(93.9\%) were positive for anti-CMV IgG antibody. Age, marital status, number of sexual partners, CD4 cells counts and previous history of blood transfusion were the main correlates of CMV seropositivity among these patients. However, occupation, sex, highly active antiretroviral therapy (HAART) were not statistically associated with CMV seropositivity in this study.

Conclusion: This study has shown that greater percentages of HIV-1 seropositive patients had active CMV infection. It has further shown that CMV is hyperendemic in HIV-1 seropositive patients in Ilorin, Nigeria.
\end{abstract}

Keywords: CD4, CMV, HIV/AIDS, IgG, IgM, Risk factors, HAART

DOI: http://dx.doi.org/10.4314/ahs.v15i1.1

\section{Introduction}

Human cytomegalovirus (HCMV) is a ubiquitous agent that can cause infection at any time during the course of life and commonly infects individuals from diverse geographical and socio-economic backgrounds ${ }^{1-2}$. By serology, $30 \%$ to $100 \%$ of the general population exhibit prior exposure to the virus ${ }^{3}$. The virus often causes asymptomatic infection in healthy persons; when symptomatic, HCMV infection presents with three recognizable clinical syndromes ${ }^{4}$.

\section{Corresponding author:}

Iheanyi Omezuruike Okonko

Medical Microbiology Unit,

Department of Microbiology,

University of Port Harcourt,

P.M.B. 5323 Choba, East-West Road,

Port Harcourt, Nigeria 500102

E-Mail:mac2finney@yahoo.com

iheanyi.okonko@uniport.edu.ng

Tel: +2348035380891
HCMV is also a virus most frequently transmitted to developing foetus, causing birth defects in new born and immune defect in later life and increase morbidity and mortality ${ }^{5}$. About $2.0 \%$ of pregnant women have either a primary or a restricted HCMV infection during pregnancy and it is estimated that $10-20 \%$ of congenitally infected newborns show evidence of the infection 6.

Infections by HCMV continue to be an important health problem in certain patient populations, such as newborns, recipients of solid organs or bone marrow and AIDS patients. In these groups, HCMV is a major cause of morbidity and mortality. In various parts of the world, the prevalence of HCMV ranges from 40$100 \%{ }^{2}$. The risk of exposure to HCMV increases with $\mathrm{age}^{7}$. As with other herpes viruses, HCMV remains latent in the infected host throughout life and rarely reactivates to cause clinical illness except in immunocompromised individuals ${ }^{7-9}$.

HCMV infection is more prevalent in populations at 


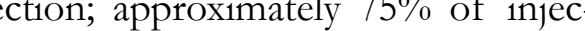
tion drug users and $>90 \%$ of homosexual men who are infected with HIV have detectable IgG antibodies to CMV [10]. HCMV infection is nearly ubiquitous in HIV-infected subjects and may lead to CMV end-organ disease (EOD) and death as a consequence of the impaired immunity ${ }^{2,7,10}$.

Prior to the introduction of combination antiretroviral therapy, HCMV EOD was common in advanced HIV infection, typically occurring with CD4 cell count of $<100$ cells $/ \mathrm{mm}^{7,10-11}$. The detection of virus- specific IgG and IgM antibodies is of great value in the diagnosis of acute/primary virus infections or reactivation of a latent one, in the absence of typical clinical symptoms.

This study aims to determine the prevalence of anti-HCMV IgG and IgM antibodies in HIV positive patients with and without past history of blood transfusion. The findings from this work may help to develop policy whether CMV screening should be routinely done before transfusing HIV infected patients, or in a case of high seroprevalence of CMV amongst the general population, the use of leukoreduced blood units for anaemic HIV infected patients, may be recommended, since CMV is transmitted through the white blood cell.

\section{Methods}

This prospective study was carried out at the University of Ilorin Teaching Hospital (UITH) Ilorin. The teaching hospital provides healthcare services to the people of Kwara and neighboring States. UITH in conjunction with the Institute of Human Virology of Nigeria (IHVN) provides free health care services to people living with HIV/AIDS in Ilorin and its environment

\section{Ethical consideraton}

A written consent was obtained from participants after carefully explaining the concept of the study to them. Ethical clearance was sought and obtained from the ethical and research committee of the University of Ilorin Teaching Hospital, Ilorin, Nigeria.

\section{Experimental design}

A total of 180 consented HIV seropositive patients attending the HAART clinic of UITH, Ilorin were recruited for this study. The demographic data of the participants were entered into a structured question- naire designed for the study. A serological survey was one by collecting blood samples from all participants for HCMV IgG and IgM. These samples were sent in Giostyle box with ice packs to preserve the cold chain to the laboratory. Serum was extracted from each sample by centrifugation at $3000 \mathrm{rpm}$ for 5 minutes using ES5 centrifuge. All the sera obtained were stored frozen at $-20^{\circ} \mathrm{C}$ until analysis was done.

\section{Blood collection and serological analysis}

Five milliliters of blood was collected into sterile anticoagulant-free bottle. Each sample was centrifuged after the blood had clotted and serum separated into sterile bottles on each collection day for storage at $-20^{\circ} \mathrm{C}$. All specimens were screened for HCMV specific-IgM and IgG antibodies using IgM and IgG ELISA Kit manufactured by DIA.PRO Diagnostic Bioprobes Srl Via Columella nO31 20128 Milano - Italy. The testswere done according to manufacturer's instructions. The cutoff of the device was set at $0.5 \mathrm{WHO} \mathrm{IU/ml} \mathrm{(Calibera-}$ tor 2) by the kit's manufacturer. Samples with a concentration higher than $0.5 \mathrm{WHO} \mathrm{IU} / \mathrm{ml}$ were considered positive for CMV $\operatorname{IgG}$ whilst samples with concentration below the cut-off were regarded as negative results. All reactive samples were repeated in duplicate for IgM tests and accepted as positive.

\section{Sensitivity and specificity of the Elisa kits}

The value, obtained from the analysis of more than 300 specimens, has been $>98 \%$ of sensitivity. An overall value $>98 \%$ of specificity was found when examined on more than 100 specimens.

\section{Data analysis}

Data was analyzed using Microsoft Excel 2007 version to calculate the International Unit (IU) from Optical Density (OD). Values below 0.5 were considered negative and values above 0.5 were considered positive. Statistical Package for Social Sciences (SPSS, version 19.0)

software was used to calculate descriptive statistics.

\section{Results}

Patients' characteristics

Of a total of 180 consented HIV-1 seropositive patients that participated in the study, $108(60.0 \%)$ were females while males were $72(40.0 \%)$ in number giving a male to female ratio of 1:1.3. Socio-demographic data of HIV1 seropositive patients tested for anti-CMV IgG/IgM antibodies are shown in Table 1 and 2. Behavioral dat of HIV-1 patients tested for anti-CMV IgG/IgM anti-
Distribution of anti-HCMV IgM antibody among

\section{HIV-1 seropositive subjects} Twenty (11.1\%) of the 180 HIV-1 seropositive subjects positive outcome of HIV-1 seropositive patients tested

Table 1: Socio-demographic data and seropositive outcome of HIV-1 patients tested for anti-CMV

\begin{tabular}{|c|c|c|c|c|c|}
\hline \multirow[t]{2}{*}{ Variables } & \multirow{2}{*}{$\begin{array}{l}\text { No. } \\
\text { Tested } \\
(\%)\end{array}$} & $\begin{array}{l}\text { No. } \\
(\%)\end{array}$ & $\begin{array}{l}\text { Statistical } \\
\text { Values }\end{array}$ & No. Positive (\%) & Statistical Values \\
\hline & & $\begin{array}{l}(\%) \\
\text { Anti-CMV IgM }\end{array}$ & & Anti-CMV IgG & \\
\hline \multicolumn{6}{|l|}{ Age (years) } \\
\hline $16-25$ & $7(3.9)$ & $1(14.3)$ & & $7(100.0)$ & \\
\hline $26-35$ & $74(41.1)$ & $10(13.5)$ & & $71(95.9)$ & \\
\hline $36-45$ & $81(45.0)$ & $8(9.9)$ & & $73(90.1)$ & \\
\hline 46andabove & $18(10.0)$ & $1(5.6)$ & $\mathrm{P}<0.05$ & $18(100.0)$ & $\mathrm{P}<0.05$ \\
\hline \multicolumn{6}{|l|}{ Sex } \\
\hline Females & $108(60.0)$ & $10(9.3)$ & & $100(92.6)$ & \\
\hline Males & $72(40.0)$ & $10(13.9)$ & $\mathrm{P}>0.05$ & $69(95.8)$ & $\mathrm{P}>0.05$ \\
\hline \multicolumn{6}{|c|}{ Marital Status } \\
\hline Single & $39(21.7)$ & $5(12.8)$ & & $38(97.4)$ & \\
\hline Married & $127(70.5)$ & $14(11.0)$ & & $118(92.9)$ & \\
\hline Others & $14(7.8)$ & $1(7.1)$ & $\mathrm{P}<0.05$ & $13(92.7)$ & $\mathrm{P}<0.05$ \\
\hline \multicolumn{6}{|l|}{ Occupation } \\
\hline Civil servants & 20(11.1) & $1(5.0)$ & & $16(80.0)$ & \\
\hline Traders & $100(55.6)$ & $16(16.0)$ & & $100(100.0)$ & \\
\hline Farmers & $10(5.5)$ & $1(10.0)$ & & $10(100.0)$ & \\
\hline Others & $30(16.7)$ & $1(3.3)$ & & $27(90.0)$ & \\
\hline Unemployed & $20(11.1)$ & $1(5.0)$ & $\mathrm{P}>0.05$ & $16(80.0)$ & $\mathrm{P}>0.05$ \\
\hline Total & $180(100.0)$ & $20(11.1)$ & & $169(93.9)$ & \\
\hline
\end{tabular}

for anti-CMV IgG/IgM antibodies. The study shows 1. Also from Table 1, it can be observed that there was significant difference in anti-CMV IgG and anti-CMV no significant difference $(\mathrm{X} 2=1.434$, $\mathrm{p}$-value $=0.591)$ IgM antibodies among the various age groups tested in the seropositivity outcome of anti-CMV IgG anti$(\mathrm{X} 2=1.454, \mathrm{p}$-value $=0.000)($ Table 1$)$. It showed that bodies among the subjects (Table 1). The level of anthe prevalence of anti-CMV IgM was higher in age ti-CMV $\operatorname{IgM}$ and $\operatorname{IgG}$ antibodies seropositivity among groups $16-25$ years $(14.3 \%)$, followed by age groups 26 - the various marital groups was also statistically signifi35 years $(13.5 \%), 36-45$ years $(9.9 \%)$ and age group 46 cant $(\mathrm{X} 2=1.306$, $\mathrm{p}$-value $=0.002)$ (Table 1$)$. The prevyears and above had the least prevalence $(5.6 \%)$. In the alence of anti-CMV IgM was higher in singles $(12.8 \%)$ same vein, the prevalence of anti-CMV IgG was higher than their married counterparts $(11.0 \%)$ and others in age groups $16-25$ years $(100.0 \%)$ and age group 46 (7.1\%). In the same vein, the prevalence of anti-CMV years and above $(100.0 \%)$, followed by age groups $26-\operatorname{IgG}$ was also higher in singles (97.4\%) than their mar35 years $(95.9 \%)$ and $36-45$ years $(90.1 \%)$ as shown in ried counterparts $(92.9 \%)$ and others $(92.7 \%)$ as shown Table 1. in Table 1.

There was no significant difference $(\mathrm{X} 2=1.784 \mathrm{p}$-val- The study shows no statistical association in the seroue $=0.629)$ in the seropositivity outcome of anti-CMV positivity outcome of anti-CMV IgM antibody among IgM antibody among the two sex groups. The preva- the various occupational groups (Table 1). Also from lence of anti-CMV IgM was higher in males (13.9\%) Table 1, it can be observed that there was no significant than their female counterparts $(9.3 \%)$. In the same vein, difference $(X 2=1.434$, $\mathrm{p}$-value $=0.591)$ in the seroposthe prevalence of anti-CMV $\operatorname{IgG}$ was also higher in itivity outcome of anti-CMV IgG antibodies among the males $(95.8 \%)$ than females $(92.6 \%)$ as shown in Table subjects (Table 1). The prevalence of anti-CMV IgM 
was higher among traders $(16.0 \%)$, followed by farmers the level of anti-CMV IgM and anti-CMV IgG antibod(10.0\%) civil servats $(5.0 \%)$ and unemployed subjects $(5.0 \%)$ while other occupations had the least preva- (Table 2). The prevalence of anti-CMV IgM was higher lence of anti-CMV IgM (3.3\%). In the same vein, the among subjects who were not on HAART (54.4\%) than prevalence of anti-CMV IgG was higher among trad- those on HAART (45.0\%). In the same vein, the prevaers $(100.0 \%)$ and farmers $(100.0 \%)$, followed by other lence of anti-CMV IgG was higher among subjects who occupations $(90.0 \%)$, civil servants $(80.0 \%)$ and unem- were not on HAART $(94.4 \%)$ than those on HAART ployed subjects $(80.0 \%)$ as shown in Table 1.

Behavioral data and seropositivity outcomes of HIV-1 seropositive patients tested for anti-CMV IgG/IgM antibodies

Table 2 shows the behavioral data and seropositivity outcomes of HIV-1 seropositive patients tested for anti-CMV $\operatorname{IgG} / \mathrm{IgM}$ antibodies. Our study also found significant difference $(\mathrm{X} 2=24.25$, $\mathrm{p}$-value $=0.000)$ in the seropositivity of anti-CMV $\operatorname{IgM}$ and $\operatorname{IgG}$ antibodies among those with single $8.5 \%$ for $\operatorname{IgM}$ and $86.4 \%$ for $\operatorname{IgG})$ and multiple sexual partners $(12.4 \%$ for $\operatorname{IgM}$ and $97.5 \%$ for $\operatorname{IgG}$ ) as shown in Table 2 . The study shows no significant difference $(\mathrm{X} 2=0.080$, $\mathrm{p}$-value $=0.777)$ in

$(90.0 \%)$ $\left(90.0^{\circ}\right)$ as shown in Table 2 . The results showed that of the $40(22.2 \%)$ subjects with previous history of blood transfusion; 6(15.0\%) were seropositive for anti-CMV IgM and 38(90.0\%) for anti- CMV IgG antibody. While among those with no history, 14(10.0\%) were positive for anti-CMV antibody. There was significant difference $(\mathrm{X} 2=1.412$, $\mathrm{p}$-value $=0.000)$ in the level of anti-CMV IgM and an ti-CMV IgG antibodies among the two groups (Table 2). The CD4 cell counts ranged from 17 - 321 cells $\mathrm{mm}^{3}$. There was significant association $(\mathrm{X} 2=1.155$, $\mathrm{p}$-value $=0.0000$ ) between CD4 cells count and seropositivity outcome of HIV-1 seropositive patients tested for anti-CMV IgM and anti-CMV IgG antibodies ( $\mathrm{Ta}-$ ble 2)

Table 2: Behavioral data and seropositivity outcomes of HIV-1 patients tested for anti-CMV IgG/IgM antibodies

\begin{tabular}{|c|c|c|c|c|c|}
\hline \multirow[t]{2}{*}{ Variables } & \multirow[t]{2}{*}{$\begin{array}{ll}\text { No. } & \text { Tested } \\
(\%) & \end{array}$} & $\begin{array}{l}\text { No. Positive } \\
(\%)\end{array}$ & \multirow[t]{2}{*}{$\begin{array}{l}\text { Statistical } \\
\text { Values }\end{array}$} & \multirow{2}{*}{$\begin{array}{l}\begin{array}{l}\text { No. Positive } \\
(\%)\end{array} \\
\text { anti-CMV IgG }\end{array}$} & \multirow[t]{2}{*}{$\begin{array}{l}\text { Statistical } \\
\text { Values }\end{array}$} \\
\hline & & anti-CMV IgM & & & \\
\hline \multicolumn{6}{|c|}{ Sexual Partners } \\
\hline $\begin{array}{l}\text { Single } \\
\text { Multiple }\end{array}$ & $59(32.8)$ & $5(8.5)$ & & $51(86.4)$ & \\
\hline \multicolumn{6}{|c|}{ On HAART } \\
\hline Yes & $20(11.1)$ & $9(45.0)$ & & $18(90.0)$ & \\
\hline No & $160(88.9)$ & $11(54.4)$ & $\mathrm{P}>0.05$ & $151(94.4)$ & $\mathrm{P}>0.05$ \\
\hline \multicolumn{6}{|c|}{ Blood Transfusion } \\
\hline Yes & $40(22.2)$ & $6(15.0)$ & & $38(90.0)$ & \\
\hline No & $140(77.8)$ & $14(10.0)$ & $\mathrm{P}<0.05$ & $131(93.6)$ & $\mathrm{P}<0.05$ \\
\hline \multicolumn{6}{|c|}{$\mathrm{CD}_{4}$ count $(\mathrm{Cellis} / \mathrm{mm} 3)$} \\
\hline$<50$ & $24(16.5)$ & $2(8.3)$ & & $21(87.5)$ & \\
\hline $51-100$ & $59(34.5)$ & $8(13.6)$ & & $54(91.5)$ & \\
\hline $101-150$ & $41(21.0)$ & $4(9.8)$ & & $39(95.1)$ & \\
\hline $151-200$ & $16(8.0)$ & $1(6.3)$ & & $15(93.7)$ & \\
\hline $201-250$ & $8(4.0)$ & $1(12.5)$ & & $8(100.0)$ & \\
\hline $251-300$ & $16(8.0)$ & $3(18.8)$ & & $16(100.0)$ & \\
\hline$>300$ & $16(8.0)$ & $1(6.3)$ & $\mathrm{P}<0.05$ & $16(100.0)$ & $\mathrm{P}<0.05$ \\
\hline Total & $180(100.0)$ & $20(11.1)$ & & $169(93.9)$ & \\
\hline
\end{tabular}

Cytomegalovirus (CMV) is a very frequent infection complicating AIDS. Sexual transmission appears to be the most common route of infection in adults, though CMV can also be spread through oropharyngeal sections, urine, breast milk, and blood ${ }^{12-13}$. CMV-specific antibody of the IgM class is a marker of active or recent primary infection with the virus. Post-transfusion CMV infection correlates positively with the receipt of blood from CMV IgM-positive donors ${ }^{14}$. A decreased incidence of Transfusion associated-CMV infection was reported when only blood products negative for CMV IgM were used ${ }^{15}$. Most patients with AIDS who develop clinical signs and symptoms of CMV infection probably have reactivation of previous infection rather than primary infection ${ }^{12-13}$. The prevalence of HIV/ AIDS in Sub Saharan Africa is high but the description of CMV infection as opportunistic infection amongst patients is scanty ${ }^{13}$.

The aims of this study were to determine the prevalence of CMV infection in HIV positive patients with and without past history of blood transfusion and compare our findings with those of other studies. The study reports that $11.1 \%$ of the HIV-1 seropositive patients tested were anti-CMV IgM seropositive and $93.9 \%$ were positive for anti-CMV IgG antibody.

This finding is in consonance with what has been previously reported. Akinsola et al. ${ }^{16}$ reported few cases of CMV retinitis in HIV infected Nigerians. The HIV patients who developed symptomatic CMV infection may have had the infection for a long time; immunosupression by HIV makes the virus to become pathogenic ${ }^{13}$. The higher the prevalence of CMV in the general population, the higher should be the prevalence of CMV infection in the population of HIV infected patients ${ }^{13}$.

The $93.9 \%$ reported for anti-CMV IgG antibody seropositivity in this study is comparable to the values reported in previous studies in Nigeria and outside. The seroprevalence of CMV IgG of $96.0 \%$ was reported by Akinbami et al. ${ }^{1}$ in Lagos, Nigeria. Okwori et al. ${ }^{1}$ reported a seroprevalence of $84.2 \%$ among pregnant women. Similar seroprevalence rates of $90.0-100.0 \%$ were also found in India ${ }^{18-20}$. The high seroprevalence in Nigeria and India contrasts with Western literature, in which seroprevalence ranges from $38.0 \%$ to $75.0 \%$. A seroprevalence of $40.0 \%$ was found in highly industrialized nations ${ }^{8}$. Uyar et al. ${ }^{21}$ reported a $97.3 \%$ and $1.0 \%$ ntibodies respectively in Northern Turkey.

The seroprevalence of CMV IgG of 100.0\% among healthy blood donors was also found in the study of $\mathrm{Krech}^{8}$ done at Ibadan, Nigeria in 1973. A high seroprevalence of between $90-100 \%$ was also found in India amongst immunocompetent subjects in various studies ${ }^{13}$. Atul and Ramanchandrum ${ }^{20}$ found $95.0 \%$ seroprevalence of CMV IgG amongst blood donors. A study by Pal et al. ${ }^{18}$ in 1972 showed $100.0 \%$ seropositivy for CMV IgG in a population of immunocompetent dults. Madhavan et al. ${ }^{19}$ in 1974 showed that $84-96 \%$ of immunocompetent adults had the antibody.

The study showed that the seropositivity of anti-CMV IgG and anti-CMV IgM antibodies were age dependent. The positivity for anti-CMV IgG and anti-CMV IgM antibodies was not found to be the same in all age groups. The age-related distribution of anti-CMV-specific IgM antibodies among the HIV-1 seropositive subjects showed a significant difference in the levels of anti-CMV IgG and anti-CMV IgM antibodies among the various age groups tested $(\mathrm{p}=0.000)$. This is also in keeping with the findings of previous studies. CMV infections occurs worldwide, about four out of five people over age 35 have been infected with cytomegalovirus, usually during childhood or adulthood $^{22}$. In most of these people, the disease is so mild that it is overlooked ${ }^{23}$.

In line with a study by Dollard ${ }^{24}$, seroprevalence was also found to be age-dependent. Dollard ${ }^{24}$ reported $58.7 \%$ of individuals aged 80 and older were positive to CMV. Pal et al ${ }^{18}$ in Chandigarh, India, showed $100.0 \%$ seropositivity for $\mathrm{CMV}$ in the population aged $>20$ years, while Madhavan et al. ${ }^{19}$ in Pondicherry showed that $84.0-96.0 \%$ of adults had the antibody. According to Abu-Madi et al. ${ }^{25}$, most of the children and adolescents in Qatar, Arabian Gulf, appear to have been exposed to CMV with seroprevalences of $79.0 \%$ in the 2 to 10 -year and $91.0 \%$ in the 11 to 20 year age groups ${ }^{25}$. Kassim et al. ${ }^{26}$ reported that $91.0 \%$ of 33 mothers were seropositive for CMV compared to $33.0 \%$ of their infants ${ }^{17}$

Our study showed that the prevalence of anti-CMY $\mathrm{IgG}$ and $\mathrm{IgM}$ antibodies was not sex dependent. The seropositivity for anti-CMV IgG and IgM antibodies was found to be the same in both males and females. 
Though, there was no significant difference $(\mathrm{p}=0.591)$ in the level of anti-CMV IgG and IgM antibodies among the subjects, sex-related distribution of CMV IgM among the HIV-1 seropositive subjects showed that of the 108 females tested, $10(9.3 \%)$ were anti-CMV IgM positive and $10(13.9 \%)$ of the 72 males tested were CMV IgM positive. Also from Table 1, it can be observed that of the 108 females tested, $100(92.6 \%)$ were anti-CMV IgG positive and $69(95.8 \%)$ males were positive for anti-CMV IgG. Existing evidence suggests that the concentrations of $\operatorname{IgG}$ immunoglobulin in maternal and cord sera are essentially the same ${ }^{2}$.

In this study, a seroprevalence of $92.6 \%$ for CMV IgG and $9.3 \%$ for CMV IgM was observed in females. This is a deviation from what was reported by earlier workers in Nigeria and outside Nigeria ${ }^{17,27-30}$. In Brazil, 94.7\% prevalence rate was reported among females ${ }^{30}$. In Gambia, $14.0 \%$ of 178 Gambian babies were congenitally infected despite the fact that $87.0 \%$ of their mothers were antibody positive to $\mathrm{CMV}^{28}$. At the time of delivery of $96.0 \%$ of the 150 Egyptian mothers and their newborn infants were CMV-IgG seropositive ${ }^{29}$ This study has shown that those females with CMV IgG antibodies can efficiently transferred the antibodies to their developing foetus, if pregnant. This may be due to the fact that $\operatorname{IgG}$ antibody is unique among the major immunoglobulin classes for its active transfer across maternal placenta ${ }^{25,31}$.

Transmission of CMV is sexual ${ }^{24}$. Among the 59 $(32.8 \%)$ HIV-1 seropositive individuals with single sexual partners, $5(8.5 \%)$ were anti-CMV IgM seropositive and $51(86.4 \%)$ were anti-CMV IgG seropositive. Of the 121(67.2\%) HIV1-seropositive individuals with multiple sexual partners, $15(12.4 \%)$ were CMV IgM seropositive and $118(97.5 \%)$ were anti-CMV $\mathrm{IgG}$ seropositive. The study statistical association in the seropositivity outcome of anti-CMV IgM and anti-CMV IgG antibodies and the number of sexual partners.

This study also determines the immune status of HIV1 seropositive patients to CMV in Ilorin. In the studied population, $88.9 \%$ of the HIV seropositive patients and $97.4 \%$ of the HIV negative controls were immun to CMV. The implication of these findings is that individuals seronegative for CMV are susceptible to CMV primary infections ${ }^{21}$. The $\mathrm{CD} 4$ cell counts-related distribution of CMV IgM and IgG antibodies among the re- ruited HIV sero-positive subjects showed a significant association (X2 $=1.155$, $\mathrm{p}$-value $=0.0000)$ between cells count and CMV IgM seropositivity. It showed that their $\mathrm{CD} 4$ cell counts ranged from $17-321$ cells $/ \mathrm{mm}^{3}$. Majority, 69(34.5\%) had CD4 cell counts which ranged from 201-250 cells $/ \mathrm{mm} 3$ while the minority had CD4 counts which ranged from 201-250 cells $/ \mathrm{mm}^{3}$. From Table 2, it can be seen that majority, 8 (13.6\%) out of the 20 CMV IgM sero-positive individuals had CD4 cell counts which ranged from $51-100$ cells $/ \mathrm{mm}^{3}$ while 2 $(8.3 \%)$ had CD4 cell counts of $<50$ cells $/ \mathrm{mm}^{3}$.

The distribution of anti-CMV IgM and anti-CMV $\operatorname{IgG}$ in relation to marital status showed statistical association $(\mathrm{X} 2=1.306$, $\mathrm{p}$-value $=0.002)$ in the anti-CMV seropositivity among the various marital groups. From the result, it can be deduced that $14(11.0 \%)$ of the married subjects were anti-CMV IgM positive and $118(92.9 \%)$ were anti-CMV IgG positive, compared with the $12.8 \%$ seropositivity observed among singles and 7.1\% among others (widows/widowers/divorced). Also, 118(92.9\%) of the married were anti-CMV IgG positive and compared to $97.4 \%$ seropositivity among singles and $92.7 \%$ among others.

In term of their HAART status, it can be seen that nin $(45.0 \%)$ out of the 20 that were CMV IgM positive were already on HAART, while $87(54.4 \%)$ out of the 160 that were not yet on HAART were also found to be CMV IgM sero-positive. There was no significant difference $(\mathrm{X} 2=0.080$, $\mathrm{p}$-value $=0.777)$ in the level of CMV IgM among the HIV-1 sero-positive individuals tha $t$ were on HAART and those that were not.

CMV-specific antibody of the IgM class is a marker of active or recent primary infection with the virus. Transmission of CMV is also congenital (in birth), through blood product or transplantation, and person to person (e.g. day care centres $)^{24}$. CMV infection constitute a real risk of pathogenicity in immunocompromised patient, it is likely that HIV infected patients who develop CMV infection may have a previous history of blood transfu$\operatorname{sion}^{13}$. Also HIV infected patients who require transfusion are at high risk of developing symptomatic CMV infection when they are transfused with CMV infected donor blood ${ }^{13}$. However, our present study showed no significant difference $(\mathrm{X} 2=1.412$, $\mathrm{p}$-value $=0.837)$ in the level of CMV IgM among those with history of blood transfusion and those with no such history.
The results showed that of the $40(22.2 \%)$ subjects with previous history of blood transfusion; $6(15.0 \%)$ were seropositive for anti-CMV IgM and $38(90.0 \%)$ for anti-CMV IgG antibody. While among those with no history, 14(10.0\%) were positive for anti-CMV IgM and $131(93.6 \%)$ for anti-CMV IgG antibody. This is at variance with the work of Tolpin and Stewart ${ }^{32}$ in 1985 that provided the first biochemical and molecular evidence for transfusion associated-CMV infection. Likelihood of transfusion in HIV infected patient is found to be at least three times higher when compared with transfusion in all other patients in the medical wards ${ }^{33}$. Thus, predisposing them further to the risk of ac quiring CMV infection through blood transfusion ${ }^{13}$. Although, some authorities are of the opinion that the assertion claiming the individuals with IgM anti-CMV are more likely to transmit the virus than those with IgG anti-CMV is not proven beyond doubts ${ }^{15}$. Lamberson et al. ${ }^{15}$ found that a decreased incidence of transfusion-associated -CMV (TA- CMV) infection occurred when only blood products negative for CMV IgM were used.

Furthermore, the seropositivity of CMV varies widel in the world. A number of studies reveal a CMV seroprevalence of $56.3 \%$ in Finnish pregnant women ${ }^{34,21}$, $78.0 \%$ in Russian pregnant women ${ }^{21,35} 87.5 \%$ in pregnant women from Singapore ${ }^{36,21}$ and $92.1 \%$ in pregnant women from Saudi Arabi ${ }^{37,21}$ Gratacap-Cavallier al. ${ }^{38}$ found that CMV seroprevalence was significantly higher in women born in southern France $(51.6 \%)$ than in those born in northern France $(37.4 \%)^{21}$. The prevalences of anti-CMV IgG antibody reported in this study was also found similar to that of other studies reported in Turkey and other developing countries. CMV seroprevalence was reported to be $84.3 \%$ from Afyon, Turkey $^{21,39}, 92.6 \%$ from Ankara, Turkey ${ }^{40,21}, 92.6 \%$ from Aydin, Turkey ${ }^{41,21,} 94.9 \%$ from Antalya, Turkey ${ }^{21,42}$ and $97.3 \%$ from Hatay, Turkey ${ }^{43,21}$.

The detection of virus-specific IgG and IgM antibodies is of great value in the diagnosis of acute/primary viru infections or reactivation of a latent one, in the absence of typical clinical symptoms. Asymptomatic infections usually happen for CMV in apparently healthy individuals, during pregnancy and several diseases as a coinfective agent. The high CMV seroprevalence found in this study underscores the importance of using strategies to provide "CMV safe" blood to Haematologic Disorde
Patients (HDPs) who are at high risk of developing severe CMV infection ${ }^{3}$.

\section{Conclusion}

This study has shown that greater percentages of HIV1 seropositive patients had active CMV infection. It has further shown that CMV is hyperendemic in HIV-1 seropositive patients in Ilorin, Nigeria. Unfortunately, vaccines for CMV have not yet been developed ${ }^{44}$. Preventive measures must be taken to decrease the mortality and morbidity related to CMV infections ${ }^{21}$. There is therefore need to routinely screen blood donors and preonant women for evidence of CMV infection during their transfusion and antenatal visits respectively.

\section{References}

1. Akinbami AA, Akanmu AS, Adeyemo TA, Wright KO, Dada MO, Dosunmu AO. Cytomegalovirus antibodies among healthy blood donors at Lagos University Teaching Hospital. South African Medical Journal, 2009; 99 (7): 528-530

2. Spector SA, Wong R, Hsia K, et al. Plasma cytomegalovirus (CMV) DNA load predicts CMV disease and survival in AIDS patients. J Clin Invest. 1998; 101: 497-502

3. de Matos SB, Meyer, R, de Mendonça Lima, FW. Seroprevalence and serum profile of cytomegalovirus infection among patients with hematologic disorders in Bahia State, Brazil. Journal of Medical Virology, 2010; 83 (2): 298-304

4. Dollard, SC. Seroprevalence of Cytomegalovirus Infection in the United State. Clinical Symptoms, 2006; 43(9): 1143-1151.

5. Caruso CB. Mechanisms of immunosense Scene". Immunity and Ageing, 2009; 6:40-50

6. Stern H, Tucker SM. Prospective Study of Cytomegalovirus Infection in pregnancy. British Medical Journal, 1973; 2: 168-270.

7. Wohl DA, Zeng D, Stewart P, et al. Cytomegalovirus viremia, mortality, and end-organ disease among patients with AIDS receiving potent antiretroviral therapies. Journal of Acquired Immunodeficiency Syndrome, 2005; 38:538-544.

8. Krech U. Complement-fixing antibodies against cytomegalovirus in different parts of the world. Bulletin

of World Health Organization 1973; 49(1):103-106.

9. Grefte A, van der Giessen M, van Son W, The

TH. Circulating cytomegalovirus (CMV)-infected en- 
dothelial cells in patients with an active CMV infection. Journal of Infectious Diseases, 1993; 167 (2):270-277.

10. Reus S, Portilla J, Gimeno A, et al. [Predictors of progression and death in patients with advanced HIV infection in the era of highly active antiretroviral therapy]. Enferm Infec Microbiology Clinics, 2004; 22:142149.

11. Deayton JR, Prof Sabin CA, Johnson MA, et al Importance of cytomegalovirus viraemia in risk of disease progression and death in HIV-infected patients receiving highly active antiretroviral therapy. Lancet. 2004 363:2116-2121.

12. Klatt EC, Shibata D. Cytomegalovirus infection in the acquired immunodeficiency syndrome: clinical and autopsy findings. Arch Pathol Lab Med. 1988; 112:540544.

13. Akinbami AA, Akanmu AS, Adeyemo TA, Wrigh KO, Dada MO, Dosunmu AO. Cytomegalovirus Antibodies Amongst Immunocompromised (HIV) Patients At Lagos University Teaching Hospital (LUTH) Idi -Araba, Lagos. Journal of Medicine, 2010; 11 : 151-154 14. Lentz EB, Dock NL, McMahon CA, Fiesthumel SR, Arnold CB, Lamberson HV. Detection of anti-body of cytomegalovirus-induced early antigens and comparison with four serologic assays and presence of viruria in blood donors. Journal of Clinical Microbiology, 1988; 26: 133-135.

15. Lamberson HV, Jr., McMillan JA, Weiner LB, Williams ML, Clark DA, McMahon CA et al. Prevention of transfusion associated cytomegaloviral infection in neonates by screening blood donors for IgM to CMV. Journal of Infectious Diseases, 1988; 157:820-823.

16. Akinsola FB, Okany CC, Majekodunmi AA, Akinsete I. Ocular Manifestations of HIV Infections in Lagos University Teaching Hospital. The Nigeria Postgradu ate Medical Journal 1997.Vol. 4, No, 3, 09

17. Okwori AEJ, Olabode AO, Emumwen EG, Echeonwu GO, Lugos MO, Okpe ES, Okopi JA, Adetunji JA. Sero-Epidemiological Survey of Human Cytomegalovirus Infection among Expectant Mothers in Bida, Nigeria. The Internet Journal of Infectious Diseases, 2009; Volume 7 Number 1.

18. Pal SR, Chitkara NK, Krech V. Seroepidemiolo-

gy of cytomegalovirus infection in and around

Chandigarh. Indian Journal of Medical Research, 1972; 60 973-978.

19. Madhavan HN, Prakash K, Agarwal SC. Cytomegalovirus infections in Pondicherry: a serological survey. Indian Journal of Medical Research, 1974; 62: 297-300. 20. Atul Kothari, VG Ramachandrum et al. Seroprevalence of Cytomegalovirus among voluntary blood
33. Akanmu AS, Esan OA, Taiwo-Osinubi P. Transfusion dependent Anaemia: A common indication of admission in HIV-infected patients at the Lagos University Teaching Hospital.4th National Conference on HIV/AIDS. International conference centre Abuja, 2004 May 2-5.

34. Alanen A, Kahala K, Vahlberg T, Koskela P, Vainionpaa R. Seroprevalence, incidence of prenatal infections and reliability of maternal history of varicell zoster virus, cytomegalovirus, herpes simplex virus and parvovirus B19 infection in South-Western Finland. BJOG, 2005; 112 (1): 50-56. Stray-Pedersen B. Seropositivity of cytomegalovirus, parvovirus and rubella in pregnant women and recurrent aborters in Leningrad County, Russia. Acta. Obstetrics and Gynecology Scand., 2001; 80 (11): 1025 1029.

36. Wong A, Tan KH, Tee CS, Yeo CSH. Seroprevalence of Cytomegalovirus, Toxoplasma and Parvovirus in Pregnancy. Singapore Medical Journal, 2000; 41(4), 151 155.

37. Ghazi HO, Telmesani AM, Mahomed MF. (2002). TORCH Agents in Pregnant Saudi Women. Medical Principles and Practice, 2002; 11: 180-182

38. Gratacap-Cavallier B, Bosson JL, Morand P, Dutertre N, Chanzy B, Jouk PS, Vandekerckhove C, CartLamy P, Seigneurin JM. (1998). Cytomegalovirus sero-
35. Odland JO, Sergejeva IV, Ivaneev MD, Jensen IP,

prevalence in French pregnant women: parity and place of birth as major predictive factors. European Journal of Epidemiology, 1998; 14 (2), 147-152.

39. Altindis M, Tanir HM. Gebe kadinlarda Toxoplasma gondii ve Sitomegalovirus antikorlari siklig ${ }^{\curlyvee}$. Genel. Tip. Dergisi., 2002; 12 (1): 9-13

40. Yücel A, Bozdavi B, Imir T. Seroprevalence of TORCHE antibodies among pregnant women in Gazi University Hospital. Turkish Journal of Infection, 2002; 16 (3): 279-283.

41. Yilmazer M, Altindis M, Cevrioglu S, Fenkci V, Aktepe O, Sirthan E. Toxoplasma, Cytomegalovirus, Rubella, Hepatitis B and Hepatitis C seropositivity rates in pregnant women who live in Afyon Region. Medical Journal Kocatepe, 2004; 49-53.

42. Satilmis A, Güra A, Ongun H, Mendilcioglu I, Çolak $\mathrm{D}$, Oygür N. CMV seroconversion in pregnants and the incidence of congenital CMV infection. Turkish Journal of Pediatrics, 2007; 49: 30-36.

43. Ocak S, Zeteroglu S, Ozer C, Dolapcioglu K, Gungoren A. Seroprevalence of Toxoplasma gondii, rubella and cytomegalovirus among pregnant women in southern Turkey. Scand. Journal of Infectious Diseases, 2007; 39 (3): 231-234

44. Robinson JL, Lee BE, Preiksaitis JK, Plitt S, Tipples GA. Prevention of congenital rubella syndromewhat makes sense in 2006? Epidemiology Review, 2006; 33(2): 75-7

27. Peter FK, Richard SF. Elevation of cord over maternal IgG immunoglobulin: evidence for an active placental IgG transport. Nature, 1966; 210: 1070 - 1071

28. Bello C, Whittle H. Cytomegalovirus infection in Gambian mothers and their babies. Journal of Clinical Pathology, 1991; 44: 366-369.

29. El-Nawawy A Ashraf T, Soliman, El Azzoun O, El-Sayed, A, Mohammed Abdel Karim, Soheir Demian, El-Sayed M. Maternal and Neonatal Prevaence of Toxoplasma and Cytomegalovirus (CMV) Antibodies and Hepatitis-B Antigens in an Egyptian Rura Area. Journal of Tropical Pediatrics, 1996; 42(3):154-157. 30. Adisa TM, Bukbuk DN, Harry TO. Maternofoetal transfer of Cytomegalovirus IgG antibodies in Maiduguri, North Eastern Nigeria. The Internet Journal of Microbiology, 2008 Volume 4 Number 2

31. Virella G, Nunes MAS, Tamagnini G. Placental transfer of Human $\operatorname{IgG}$ subclasses. Clinical and $\mathrm{Ex}-$ perimental Immunology, 1972; 10: 475 - 478.

32. Tolpin MD, Stewart JA, Warren D, Mojica BA, Collins MA, Doveikis SA, Cabradilla C, Schauf V, Raju T, Nelson K. Transfusion transmission of cytomegalovirus confirmed by restriction endonuclease analysis. Journal of Pediatrics, 1985;107:953-956. 